\title{
ERRATA
}

\section{Enterobacterial Common Antigen-Tetanus Toxoid Conjugate as Immunogen}

CZESŁAW ŁUGOWSKI, MAŁGORZATA KUŁAKOWSKA, AND ELŻBIETA ROMANOWSKA

Laboratory of Microbial Immunochemistry, Institute of Immunology and Experimental Therapy, Polish Academy of Sciences, 53-114 Wroctaw, Poland

Volume 42, no. 3, p. 1086, column 2, line 39: " $\mathrm{NaSO}_{4}$ " should read " $\mathrm{NaIO}_{4}$."

Page 1087, column 1, line 21: "8239" should read "(23)."

Page 1087, column 1, line 43: "IgC" should read "IgG."

Page 1089, Fig. 4 legend: The legend should read: "Comparison of ECA preparations originating from various bacterial strains run against anti-ECA-TT serum by tandem crossed immunoelectrophoresis. (A) ECA from $S$. sonnei phase II (1, $10 \mu \mathrm{g}$ ) and ECA from $S$. sonnei phase I $(2,10 \mu \mathrm{g})$. (B) ECA from $S$. montevideo $(1,10 \mu \mathrm{g})$ and ECA from $S$. sonıci phase I (2, $5 \mu \mathrm{g})$. For the conditions of electrophoresis, see the legend to Fig. 1.

\section{Expression of a Cloned Staphylococcus aureus $\alpha$-Hemolysin Determinant in Bacillus subtilis and Staphylococcus aureus}

NEIL FAIRWEATHER, SHEILA KENNEDY, TIMOTHY J. FOSTER, MICHAEL KEHOE, AND GORDON DOUGAN

Department of Microbiology, Moyne Institute, Trinity College, Dublin 2, Ireland and Department of Molecular Biology, Wellcome Research Laboratories, Langley Court, Beckenham, Kent, England

Volume 41, no. 3, p. 1113, Table 2: The entries for pXZ111 and pX2105 should read

$\begin{array}{lll}\text { pXZ105 } & \mathrm{Km}^{\mathrm{r}} \mathrm{Cm}^{\mathrm{r}} & \text { pUB110 carrying a 1,031-base pair MspI-Mbol fragment encoding Cm }{ }^{\mathrm{r}} \text { derived } \\ \text { pXZ111 } & \mathrm{Km}^{\mathrm{r}} \mathrm{Hla}^{+} & \text {from pC194 }\end{array}$

$\mathrm{Km}^{\mathrm{r}} \mathrm{Hla}^{+} \quad$ pXZ105 carrying a 3.0-kbp fragment of pDU1148 encoding $\alpha$-toxin This study

\section{Differential Complement Activation and Susceptibility to Human Serum Bactericidal Action by Vibrio Species}

M. L. TAMPLIN, S. SPECTER, G. E. RODRICK, AND H. FRIEDMAN

Department of Medical Microbiology and Immunology and Comprehensive Medicine, University of South Florida College of Medicine, Tampa, Florida 33612

Volume 42, no. 3, p. 1189, column 2, line 22: “(13)” should be deleted. 